\title{
Islamophobia and Media Framing in West Media
}

\author{
Nikmah Suryandari \\ Prodi Ilmu Komunikasi Fakultas Ilmu Sosial dan Ilmu Budaya \\ Universitas Trunojoyo Madura, Indonesia \\ email: nikmahsuryandari@trunojoyo.ac.id \\ Syamsul Arifin \\ Fakulti Sains Sosial Gunaan \\ Universiti Sultan Zainal Abidin Terengganu, Malaysia \\ email: syamsul_arifin2306@yahoo.com
}

\begin{abstract}
The focus of this article is to explain the lousy illustration of Islam and Muslims in international media. The media worldwide is considered the most influential medium that's formed the views of human beings related to each phase of societies. The media carry out a massive position in building the listener perspective and mindset related to any problem that emerges within the whole globe. In this context, the audiences take delivery as genuine. They expect from media to symbolize a clean photo relate to any affair which is taking place at each countrywide and international floor. In western media, Muslims are represented as an "other alien" on a global level. After September 11, Muslims and Islam have recognized as backward and violent traditions and faith. Muslim communities and their households are generally sufferers and focused via non-Muslims, victimization of a veiled Muslim girl and religious guys in public locations, as victims and targeted against the law. In gift days, Islam and Muslims are represented as a terrorist, illiterate, extremist and backward in global media. Although the framing of Muslims and Islam, mainly after the 7/7 bombing, September 11 terrorist assault, and Paris assault, a
\end{abstract}

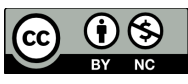

DOI: 10.19105/karsa.v29i1.3793 
massive number of look at and research installation, that the world over the inclination of media reporting is exceedingly located negativity in the direction of Islam and Muslims, through affiliating it with extremism and terrorism.

[Fokus artikel ini adalah menjelaskan ilustrasi buruk tentang Islam dan Muslim di media internasional. Media di seluruh dunia dianggap sebagai media yang paling berpengaruh, yang membentuk pandangan manusia terkait dengan setiap fase masyarakat. Media mengambil posisi yang sangat masif dalam membangun cara pandang dan pola pikir khalayak terkait dengan permasalahan yang muncul di dunia global. Dalam konteks ini, khalayak menganggap penyampaian di media sebagai sebuah kenyataan. Mereka berharap media dapat menyimbolkan foto bersih terkait segala peristiwa yang terjadi di setiap lantai nasional dan internasional. Di media barat, Muslim direpresentasikan sebagai "alien lain" di tingkat global. Setelah insiden 11 September, Muslim dan Islam tradisi dan keyakinan yang terbelakang dan penuh kekerasan. Komunitas Muslim dan rumah tangganya pada umumnya menjadi korban dari pelampiasan. Islam dan Muslim direpresentasikan sebagai teroris, buta huruf, ekstremis dan terbelakang di media global. Meskipun pembingkaian Muslim dan Islam, terutama setelah pemboman 7/7, serangan teroris 11 September dan serangan Paris, sejumlah besar penelitian, menjelaskan bahwa kecenderungan dunia atas pemberitaan media sangat mengarah pada hal-hal negatif yang mengarah pada kaum muslim dan Islam melalui afiliasi dengan ekstremisme dan terorisme.]

Keywords: Islamophobia; international media; framing; muslims, Islam

\section{Introduction}

The concern of this research have a look at is especially consciousness on Islamophobia and media framing of Muslims and Islam in international level. The digital and print media take into account the distributor of some ideology, that is shaped and assign in particular from framing, or the method thru which data is dependent and provided. ${ }^{1}$

1 Kimberly A. Powell, "Framing islam: An analysis of U.S. media coverage of terrorism since 9/11," Communication Studies, 2011, https://doi.org/10.1080/1051 0974.2011. 533599 .

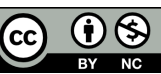

DOI: 10.19105/karsa.v29i1.3793 
Charlotte Ryan ${ }^{2}$ explains framing as, that "how information testimonies are made" and what kind of approach they used to acquire and pick out some section of information and structured it systematically to manufacture information software and memories which make clean perception to their audiences and writers. In step with Entman ${ }^{3}$, framing is a part of the information which has been selected via a few function of recognizing a few truth and assemble them extraordinarily prominent and crucial in a report and speaking messages.

In framing the media highlight on a few little pieces of data for that reason "elevating them in salience" persuasion of information values and sources of the area in which someone spending their lives, as an instance, have an impact on information tales and software production. ${ }^{4}$ An outcome of this mainstream reasoning or function, at the same time as manufacturing in the manner frame, is the reputation of headaches, causes, and representative and additionally affect ethical judgment. As stated using Entman whenever a content body has significance "in a variety of collectively reinforcing ways that the glass is half full, the proof of social science suggests that tremendously few inside the target market will finish it's miles $1 / 2$ empty". As a result, the excessive range of information insurance through words and snapshots which impose a terrible photograph of Islam and Muslims, within the context of some supportive reporting, the viewer is considered to convey off that Muslims are extremist and terrorist, in this context, media has enormous power to painting the whole global in unquestionable precise manners. The means which is interconnected to the arena can be formulated, thru numerous contradictory and distinguish strategies.

It is essential issues that what and who get into portraying, who and what frequently come by using ignored, and which context the

\footnotetext{
${ }^{2}$ Charlotte Ryan, Kevin M. Carragee, dan William Meinhofer, "Framing, the news media, and collective action," Journal of Broadcasting \& Electronic Media 45, no. 1 (2001): 175-82, https://doi.org/10.1207/s15506878jobem4501.

${ }^{3}$ Robert M. Entman, "Framing : Toward Clarification of a Fractured Paradigm SUPER RELEVANT TIL,” Journal of Communication 43, no. 4 (1993): 51-58.

${ }^{4}$ Robert M. Entman, "How the Media Affect What People Think: An Information Processing Approach," The Journal of Politics 51, no. 2 (1989): 347-70, https://doi. $\operatorname{org} / 10.2307 / 2131346$.
}

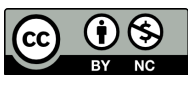

DOI: $10.19105 /$ karsa.v29i1.3793 
media represent human beings, things, occasions, and relationships. It relies upon someone stated about society and how media were painting matters to people, and what human beings get from it. What peoples do and for which kind of regulations they construct to well known. In line with this research article that how the media body one minority institution, Muslims painting in the united kingdom and the USA. however, in all likelihood talking Muslims who're living in Europe is do not forget a desperate group that is consisting of numerous contradictory traditional and cultural, historical past. ${ }^{5}$ Modood $^{6}$ moreover point out that the primary variety promotes an elaborate with the aid of socioeconomic, cultural, and political. Modood ${ }^{7}$ also advocates that the organization of British and Christian is not always complicated as Muslim institutions. The research article analyzes preceding research associated with media framing of the institution of minorities that's focusing on British press dialogue about Muslims and Islam. The illustration of British Muslims advocated the reflection of current research on how Islamophobia is framed in media. In several aspects, the media portrays Islam and Muslims as a double-edged sword. The press first off forgets about the voices of minorities; they may be thinking about successfully marginalized or out of sight. ${ }^{8}$ Simultaneously, accurate illustration of minority agencies was frequently construed in wrong discourses. ${ }^{9}$

\section{Methods}

\footnotetext{
${ }^{5}$ David Miller, A Briggs Editor, dan P Cobley Editor, "Promotion and Power," n.d. ${ }^{6}$ Elizabeth Poole, Reporting Islam, Reporting Islam, 2002, https://doi.org/10.5040/ 9780755604579.

${ }^{7}$ Tariq Modood, "Remaking multiculturalism after 7/7," Integration The Vlsi Journal, no. August (2005): 1-7, https://www.surrey.ac.uk/cronem/files/Tariq-Modood-article. pdf.

${ }^{8}$ Ibid.

${ }^{9}$ Amir Saeed, "Teaching and Learning Guide for: Media, Racism and Islamophobia: The Representation of Islam and Muslims in the Media," Sociology Compass 2, no. 6 (2008): 2041-47, https://doi.org/10.1111/j.1751-9020.2008.00160.x.
}

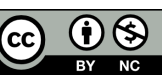

DOI: 10.19105/karsa.v29i1.3793 
The method in writing this article is a literature study. In the context of the existing analytical research article, it seeks to aim to understand coverage of Islamophobia in the media and framing Muslims in international media. This research to realize the real face of global media; this research is qualitative in nature research and provides a complete picture of Islamophobia by reviewing other papers.

\section{Results}

\section{Meaning Islamophobia}

According to the Oxford English Dictionary, Islam phobia is hatred or fear of Islam, esp. As a political force, hostility, or prejudice towards Muslims. In the context of this reference, the term Islamophobia was firstly used in 1976 in the international journal of the Middle East. The definition of Islamophobia is the alarming and fear of Islam and Muslims. An internationally the awareness of non-Muslims related to Muslims and Islam has been portraying in a very negative sense. To represent Islam and Muslims in media is conflict, ignorant, vicious, intolerant maddened terrorist, religious zealots, and distorted images are still portrayed internationally. ${ }^{10}$ Moodod declares that the step towards discrimination created in impressive Britain was were based with the aid of point out anti islamophobia software, the United State turned into providing that revel into different non-Muslims countries. ${ }^{11}$

Within the United Kingdom, the religious prejudice did not have any judicial lifestyle, no longer consisting of Northern Eire. This kind of legal guidelines aren't added merely out space in the regulation, but it additionally systems a particular system in which human equality and rights claim had been assembled. In reality, the non-Muslims community is showing a biased and discriminative mindset towards Muslims due to Islamic identity and religious movement, which communicate their injustice's act in racial phrases. Even as in media insurance and political debates, the Muslim community encompasses

\footnotetext{
${ }^{10}$ Kimberly A. Powell, "Framing Islam: An analysis of U.S. media coverage of terrorism since 9/11," Communication Studies 62, no. 1 (2011): 90-112, https://doi.org/ 10.1080/10510974.2011.533599.

${ }^{11}$ Modood, "Remaking multiculturalism after 7 / 7."
}

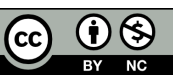

DOI: $10.19105 /$ karsa.v29i1.3793 
within the Asian institution, infrequently presenting numerous sources to their religions and belief. ${ }^{12}$ "We apprehend with deep concern the boom in anti-Semitism and Islamophobia in various components of the arena, in addition to the emergence of racial and violent movements based totally on racism and discriminatory ideas towards Jewish, Muslim and Arab communities. ${ }^{13}$ On this look at, the researcher discussed that these days the media industries are not performing their real duties, and no longer showing the actual photo of occasion and troubles. The media turns into an income-making enterprise, and an across the world news memories related to Islamophobia and Muslims are a profitable enterprise for media proprietors. That how the media pick a selected body of news tales to impact audiences, specifically in the context of Islamophobia. According to Lewis, ${ }^{14}$ international media tend to be the only one controlled through a few outstanding political agendas and extensively utilized to generate income for his or her interest. This footprint trend of media set via nations of the west after the first world battle in which the actual reasons of news and facts changed and the media grow to be the income making industry, in which businessmen, a group of few hegemonies media, their highest concentration to make the profit. An across the world in a capitalist gadget, the elite magnificence dominated the press; they have the power to control and hold the watch on problems and troubles that interconnect to propaganda and content of news, programs, and agenda putting. That turned into really considered what happened even though the incident of the arena other middle took place. The illustration of Arab and Muslims in the western media is not always presently developing fake information. At the same time, it was mounted correctly and purposeful that western human beings have been components since the first

12 Şerif Onur Bahçecik, "Internationalizing Islamophobia: Anti-Islamophobic Practices from the Runnymede Trust to the Organization of Islamic Cooperation," Ortadogu Etutleri 5, no. 1 (2013): 90, http://www.orsam.org.tr/files/OE/51/makale6. pdf.

${ }^{13}$ Ibid.

14 J. Lewis, Language Wars: The role of media and culture in global terror and political violence. (Pluto Press., 2005).

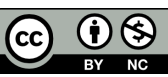

DOI: $10.19105 /$ karsa.v29i1.3793 
reference to Muslims and Arabs. in the third decade, each day in amplification of Arabs. Mainly in the time of campaign war, in the bottom to center ages, media of the west broaden all approximately the similar stereotypes for Muslims and Arabs. In the identical state of affairs, the association took place in preceding a long time, or it takes locations currently, in the west humans cope with figuring out visualizing notion in the context of Muslims and Arabs as foreigner 'other' or quite opponent even as Muslims and Arabs do not forget the manner of connection and associate with phrases have acquainted some reconstruct. ${ }^{15}$

\section{After September 11}

The terrorist assault on exchange middle in the USA on September eleven has set a selected and first-rate effect to all around the international. After a few, namely incidents like 7/7 bombing, the Muhammad cool animated film problem, the Muslim lady scarf controversy, and the Paris attacks, it has generated a prominent and big quantity of news memories coverage of Islam. In this context, the trouble of aggressiveness against Muslims and Islam emerges as the most distinguished plan that's installation via worldwide media. US news media and its follower, UK as like British Broadcasting Corporation $(\mathrm{BBC}), \mathrm{CNN}$, and some other mainstream print media, played their role in affecting the whole globe. Worldwide media are willing to narrate extremism and terrorism with Muslims and Islam.

According to Ahmed's ${ }^{16}$ research with the 9/11 incident, which acted as a catalyst, media discourse evokes Said's orientalist approach to construct meaning and Muslim identity as the 'other' in liberal societies. 9/11 influence on Western perceptions of Muslims and Islam. After 9/11, the international media focused intensively on Muslims and Islam and the Middle East in particular. Ahmed's research, too, found

15 Driss Ridouani, “The Representation of Arabs and Muslims in Western Media," RUTA: revista universitària de treballs acadèmics, no. 3 (2011).

${ }^{16}$ Saifuddin Ahmed and Jörg Matthes, "Media representation of Muslims and Islam from 2000 to 2015: A Meta-Analysis," International Communication Gazette 79, no. 3 (2017): 219-44, https://doi.org/ 10.1177/1748048516656305.

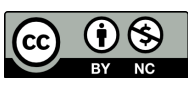

DOI: 10.19105/karsa.v29i1.3793 
plenty of research to follow $9 / 11$, themes of migration, terrorism, and war. These thematic patterns linking Muslims and Islam with terrorism, violence, and orthodox ideals, highlight religion as a threat to the rise of atavism and calls for Criticism Said's thoughts on the media As evidenced in our findings, anti-Muslim sentiments in the USA are on the rise, but elsewhere the findings remain mixed. A 2015 Pew Research Center survey corroborates our findings with most Americans perceiving Muslims unfavorably, while among European nations, only Italy and Poland were critical of Muslims; anti-Muslim sentiments in France, Germany, and the UK were not severe.

There is agreement on anti-Muslim rhetoric in the media in most countries, but this does not always result in anti-Muslim sentiments among all citizens. Therefore, research findings raise an important question about the media's influence and the ability of audiences to shape their own opinion. In the wake of the wave of recent terrorist attacks across Europe, the European Islamophobia Report found Islamophobia advancing across the board's political environment, media outlets, streets, and the business life of most European nations. ${ }^{17}$ The report suggests that acts of terrorism trigger Islamophobic activities, which was also witnessed in the USA after the 9/11 attacks. Therefore, given the current political and social crises involving Muslims in most nations, researchers investigating relationships between media and Islam should pay greater attention to how this influences perceptions and attitudes in a majority-minority milieu.

Edward stated formally indicates the prominence of media in the West that encourages and sets up an entrenched prejudice and hatred for Muslims and Islam. As passed down these days, it seems like to indicate one effortless object, besides in actual is a chunk of phase narration, a phase of the philosophical tag, an episode of a negligible nomination of religion and accept as true with known as Islam. In recent times the information media in the West have fantastic interest to gift a distorted image of Muslims and Islam. Throughout the time, specifically due to the fact occurrence in Iran takes keep of yank and European

${ }^{17}$ European Islamophobia Report, 2016.

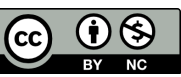

DOI: 10.19105/karsa.v29i1.3793 
concentration so completely, consequently Islam has been blanketed by way of Agha worldwide media, the media have framed it, characteristic it, inspected it, present sample direction on it, on the give up, they have constructed it familiar. This sort of media insurance in the United States of America is absolutely improper; in this context, a big challenge in point out lively reporting is depending on afar from unbiased count number. In numerous examples, Muslims and Islam have empowered now not simply impersonate incorrectness, and additionally assertion of unconstrained discriminating, societal and cultural, nonetheless hatred and racial, sizeable even unevenly brazenly recommended antagonism. ${ }^{18}$

According to McQuail ${ }^{19}$, in certain conditions, media can help the authorities managing terror issues by giving a poor label or call to terrorist agencies and generating some panic situations to terrorists thru the facts unfold. In contemporary times there are many views of people on media obligations and coverage of Muslims, Islam, and terrorism. In the time of warfare and insecurity, the media are extensively referred to as an important character in broadcasting and publishing news testimonies and programs to target the market and society. It is not stunning so that media in United Kingdom and West cover perpetuate and a consistent contorted image of Muslims and Arabs, although it's miles published or televised media. Fake and prejudice set up via Muslims and Islam are fundamental in media of the West in all types of applications, and news, even film, and dramas. In western media, the Islam and Muslims painting as a remoted existence, their objective to show them brutal evaluate typically sum up as barbaric, anti-rational, terrorism and anti-democratic and so forth. For buying their purpose, information media in the West deliberately contorted the presentation of numerous Islamic believes and ideas. ${ }^{20}$

According to Mc Quail, in an inventible situation, the authorities taking assistant from media after they cope with some terror state of

18 O. H. Agha, Islamic Fundamentalism and Its Image in the Western Media. (_al_Ahram Centre for Political et Strategic Studies., 1995).

${ }^{19}$ D. McQuail, Mass Communication Theory: An Introduction (California: Sage, n.d.). ${ }^{20}$ Ibid.

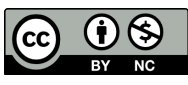

DOI: $10.19105 /$ karsa.v29i1.3793 
affairs, media put up an obstructive call or label to extremist and terrorist network and provided news stories which created a few agitations and complicated environment for the terrorist with spreading of facts. In the absence of media cooperation, terrorism is taken into consideration for the greater good sized. The contribution of media news stories every now and then creates a big confusion for the target market to glamorize the extremist and terrorist and forgotten their sufferers and brutality, in the context of exaggerating the fear and hazard of terrorist their goals and by way of denied to denounce them in each issue. In step with media news and information, to be allowed to offer promotion in addition to credibility to a few precise radical political schedule due to unique negligence built through the government, in spite all this the participation produced through the news media in constructing sensibility to related to lack of confidence of terrorist sports which then manual to create and to have a feeling of antagonism inner in communities. ${ }^{21}$ The prominent illustration of Islam and Muslims formulate them the alien, and this kind of picture is portrayed in the goodwill of them, that is premature behavior; nonetheless, they represent illiterate backward moral or unusual network who pressurize to undergo or supervise in western countries.

Dunn declares that the societal status quo of individuality is present in life within the manner of communique. Indeed, the media claimed are infinite for manufacturing an erroneous picture of Islam and Muslims like representing them as a terrorist, militant, sexist, fundamentalist, suicide bombers, violent, hijacker, enthusiast, and scripture list declare that societal status quo of individuality is present life within the manner of communique. Indeed, the media claimed are infinite for manufacturing an erroneous picture of Islam and Muslims like representing them as a terrorist, militant, sexist, fundamentalist, suicide bombers, violent, hijacker, enthusiast, and scripture list. ${ }^{22}$

The news testimonies and information articles related to Muslims and Islam were disrespectful and featured relation with

${ }^{21}$ Ibid.

${ }^{22}$ Ibid.

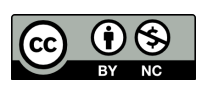

DOI: $10.19105 /$ karsa.v29i1.3793 
fundamentalist and terrorist. It is also continuously professed that Islam has a few references to centre Eastern lifestyle and Muslim 'jihad' was supplied within the antipathetic technique, and additionally choose that Islam and Muslims groups are a distinguished chance to tradition and protection of Western society. Like this kind of body of thoughts expand and encourage the concept of 'us' and 'them' that's separate fear community and facilities. ${ }^{23}$

\section{Islam in the USA and Europe}

In the United States, many instances with a distinguished profile that brings out Islamophobia have a full-size episode. There have a few cases. In cutting-edge years, in North West, London on Friday, Abdul Mutalib going to Mosque to offer prayer, became attacked by way of a few knowing people and left him injured, paralyzed and with mind injury. Every other attack was confronted utilizing Ekram Haque; he changed into lifeless outdoor in Tooting, which became severely overwhelmed. This sort of Islamophobia instance is included by way of media in a terrible sense. ${ }^{24}$

On the 7th April 2010, the yank President Obama supply guidance to dispose of that phrase which is associated with non-secular hatred and racism together with "Islamic extremism" and "jihad" from US countrywide protection private documents ("Obama bans Islam", 2010). This act confirmed authorities' attitudes concerning Muslims and Islam in Obama's time, that how practiced the world over discrimination, prejudice, and irrelevant phrases for Muslims in West. Mainly the USA media, Western and British press are considering chargeable for sowing racism and hatred seeds unreasonably, displaying and framing a prejudiced photograph of Muslims and Islam inside the mind of western humans. Islam has been represented as a faith that increases extremism, terrorism, and violence that considers a danger to the entire world. ${ }^{25}$

\footnotetext{
${ }^{23} \mathrm{O}$ Awass, The representation of Islam in the American Media (Hamdard Islamicus, 1996).

${ }^{24}$ Ibid.

${ }^{25}$ Ibid.
} 
During the terrorist attack in Norway, several western media businesses created connections with Islam. At the same time, different bluntly accused Islam and Islamic organization of the episodes without displaying any proof to guide their stance. After some research, it became more apparent that the committee of this assault became sincerely Anders Behring Breivik, a 32 year -antique Norwegian who killed at least eighty-five civilians and injured many others "Norway police." Inside the preliminary insurance of attack concentrated on Muslim present and dragged a few kind possibilities associated with an Islamic institution; specifically, Ansar al-Jihad al-Alami, or Helpers of the worldwide Jihad, refer via many professionals as claim responsibility for the assaults. American officials said the group became formerly unknown and may not even exist. There has been sufficient purpose for the subject that terrorists are probably responsible.

In this article, the researcher mentioned the essence and actual meaning of Islam and jihad; primarily, the term itself submerges in the which means of Islam is harmony and peace. It gives concept to a vital prerequisite for organizing the famous compatibility and cooperation with non-Muslims. Jihad becomes just as 2D distinct, while concord and peace are not especially seemed. Although, the influence of jihad has undertaken a progression distortion. In the begging, its connection creates for Muslims to an inhuman and murderous community of people and construct their harmony and peace violated kingdom. While depriving Muslims of their religious and non-secular implications, the western media modified the main idea of jihad and related it to extremism and terrorism. ${ }^{26}$

In this article, the representation of Islamophobia in Australian media, the portrays of Islam originate from the Middle East and overflow into Australian print and televise media, that is painting the Muslim men terrorist with the gadget gun, and beards and ladies resented as illiterate, and wear headband and hijab. Those pics originated from magazines, television, newspaper, and news packages, which distorted and overlooked the diversification of Muslim

${ }^{26}$ Ibid.

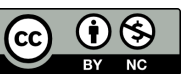

DOI: 10.19105/karsa.v29i1.3793 
communities and Islamic coaching and practices. At the give up, those humans who have the deficit of attention in the direction of Islamic coaching acquire opposite understanding and distorted photo of Muslims. The gathering of those pix, the Australian containment with discrimination, this sort of situation creates a complex political and social circumstances in which Muslim were enforced for demolishing and disgraceful claim not Australian-ness, display and sell their dedication and like to this soil. ${ }^{27}$

The researcher mentioned many activities in this study to sincerely describe Islamophobia. Dunn ${ }^{28}$ disused numerous incidents associated with anti-Muslim sentiment and racism. He advocated that Australia preserve gathered, recorded records closer to Islamophobia starting at the side of Afghan and Malay frosted, who appear like a risk and spotted closer to Australian girls. Inside the 1970s, Muslims who traveled from Lebanon and Turkey had been fabricated as backward and sexist, guiding their upcoming simulate, with every other Arab Muslim, extremist and brutal. ${ }^{29}$

Inside the 12 months of 1980 and 1990s, Australian media get up discourses on Muslim women veiling and took news reviews associated with personal damage components of an African girl. Dunn declared that Muslims are that one community who ultimately confronted troubling notably and additionally anti-Muslim sentiment and racist brutality in Australia. In this context, the Muslims who live in Australia are incredibly feeling unfortified. The exclusive research studies have explained the unique connection with each other, Islam, and global media. ${ }^{30}$ The framing of Islam and Muslim communities in

\footnotetext{
${ }^{27}$ The Age and Herald Sun, "The Representation of Islam and Muslims in the Media ( The Age and Herald Sun Newspapers ) School of Political and Social Inquiry," Islam Zeitschrift Für Geschichte Und Kultur Des Islamischen Orients, no. November (2005), http://asiainstitute.unimelb.edu.au/_data/assets/pdf_file/0017/571112/Islam-in-theMedia.pdf.

${ }^{28} \mathrm{~K}$. M. Dunn, "Representations of Islam in the politics of mosque development in Sydney," Tijdschrift voor Economische en Sociale Geografie 92, no. 3 (2001): 291308, https://doi.org/10.1111/1467-9663.00158.

${ }^{29}$ Ibid.

${ }^{30}$ Ibid.
}

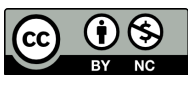

DOI: $10.19105 /$ karsa.v29i1.3793 
western media and some other elements of international media associated with Islamophobia presentation of minority agencies in a backward way. Traditionally, the relationship of exploration of western imperialism is associated with where the East and West have been developed. ${ }^{31}$

\section{Discussion}

How media negatively framed Islamophobia internationally? Does the media coverage grow Islamophobia every day to a worldwide degree? In the context of current research articles, evaluation attempted for the cause to understand the insurance of Islamophobia in media and the framing of Muslims and Islam in worldwide media. To recognize the true face of global media, this looks at qualitative studies in nature and gives exclusive photos of Islamophobia with the aid of reviewing other papers. This qualitative analysis related to Islamophobia and framing of media associated with Islam and the way international media body prejudicially Muslim and their faith.

Discussion and end according to the assessment of several studies articles have been spotting some mild on the contorted pix, prejudices, and immoderate generalizations that commonly characterize the stereotyping representation of Muslims in the western media. in the cutting-edge weather, Islam is beneath siege, and Muslim girls (and guys) 'seen' in all Western societies are susceptible to being Islamophobia victimization, labeling, stigmatization, and violence. ${ }^{32}$ Information related to Islam and Muslim by no means ever earlier then keep the primary region in media of British, present their regular exclusion from excellent stabilization, and portrayed their crucial position in dramas, truth suggests, and literature and news programs in television. In this context, explores the in particular pessimistic

\footnotetext{
31 Ibid.

32 Joseph L. Carlson, “After 9/11,” Library Journal 128, no. 9 SUPPL. (2003): 16-17, https://doi.org/10.35632/ajiss.v21i3.506.
}

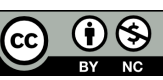

DOI: 10.19105/karsa.v29i1.3793 
hypervisibility of Islam and Muslims cover the media that has influenced the portrayal of social threat and negativity. ${ }^{33}$

The extraordinary media remark, which has in reality blended with a growing institutional splendor in portraying Islam and Muslims in press media essentially from specialists who are doing difficult work in journalism studies. Muslims and Islam are not free from headaches. The Muslims are noticeably neglected by using the Australian network. The experience of ignorance creates problems and badly harms the sentiment of the Muslim community. This is a first-rate worry in society, via which Muslims noticed the track for their issues into the clicking sheet. The media reporter constructs their social heritage and, once in a while, ideological and political substantial, in which many human beings in reality display aggression to Islam.

The difficulties of Muslim agencies have wished vigilant coverage of tales and information; the cautious reporting will provide a cognizance to a distinct type of issues that impact the principal subject affair, gift without a doubt to the target audience. Without prejudice and expert information, insurance should offer importance to knowledgeable human beings. The gift situation creates discourses related to the future of Muslims who stay in Australia and Islam. ${ }^{34}$

According to Eid, although an extraordinary variety of records sources present the distorted photos of Muslims and Islam in the belief of western humans, numerous pupils discussed the illustration of media news testimonies have an excellent effect on audience and reader. The primary and relevant source of data is considered media, and whether media offer distorted pics of a few communities is the right picture; it dramatically influences the target market due to the fact the public has blindly believe in media. In this context, the antipathetic portrayal and distribution of antagonist propaganda in Muslims and Islam in popular media in the West is not always a modern day happening. inside the

\footnotetext{
${ }^{33}$ Toby Archer, "Welcome to the umma: The British state and its Muslim citizens since 9/11," Cooperation and Conflict 44, no. 3 (2009): 329-47, https://doi.org/10.1177/ 0010836709106219.

${ }^{34}$ Age dan Sun, "The Representation of Islam and Muslims in the Media ( The Age and Herald Sun Newspapers ) School of Political and Social Inquiry."
}

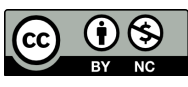

DOI: 10.19105/karsa.v29i1.3793 
studies of political and media-related debates have seemed that the illustration of Muslims and Islam in global media inclined to force discriminatory and stereotypes persuasion, discard, simply as not in bright gleam on Islam and Muslims.

The photograph of Muslims and Islam as an antipathetic "different" in western communities and typically unusual and no longer aware belief associated with Muslims and Islam are firmly allotted to the media portrayal of Muslims and Islam inside the West offered in frames "in conflict with the west and related to terrorism/extremism or violence". In the previous studies papers, the researcher anticipates that the main viewpoint of Australia, the USA, and Western coverage related to Islamophobia in global media show that Islam and Muslims are considered chance and lack confidence in their cultural values and belief. But, the representation of Muslims and Islam is brutal, backward, illiterate, terrorist, etc. Show to the general public in the West, due to the sentiment of Muslims hurt and victimize through non-Muslims in ordinary everywhere. The lives of Muslims are substantially complex because of the terrible and prejudiced representation of media. ${ }^{35}$

Islam depicted in various Western media is very provocative because the presented news tends to be negative. This news resulted in multiple labels on Islam, such as terrorist, cruel, sadistic murderer, heartless, and different other images. What matters is the role that the local media needs to play. The Western media is proven to continually target Islam by presenting a negative image and has instead become the official schedule of the media managers. As international media, the Western media is a medium and spreader of aspirations, not the other way around. The media can set agendas for deliberate reasons and set plans. For example, the Muslim veil is associated with terrorism, and Islam is a threat to the West. Orientalist perceptions of a clash culture that promote Islamophobia.

\footnotetext{
${ }^{35}$ Mahmoud Eid, "Perceptions about muslims in western societies," Re-Imagining the Other: Culture, Media, and Western-Muslim Intersections, 2014, 99-119, https://doi. org/10.1057/9781137403667.
}

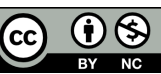

DOI: 10.19105/karsa.v29i1.3793 
As a social institution, it is hoped that there will be no media that promotes hatred, unrest, and intolerance in society. In particular, they should not exploit tensions in social relationships but focus on building social harmony. Depictions of religious and ethnic minorities in the media can drive individual thoughts towards hatred and bigotry. When setting an anti-Muslim agenda, the media with specific indicators in journalism, namely media objectivity.

\section{Conclusion}

The media's most significant role is agenda-setting - the ability to choose what issues become part of public discourse. It makes the media responsible and powerful enough to construct and present specific images to the public. According to reviews of several research articles, it has found several images in the form of prejudice and overgeneralization, which are usually considered to represent stereotypes of Muslims in western media. Islam and Muslims are currently vulnerable to being victims of labeling, stigmatization, and Islamophobic violence. The media community so severely neglects. This sense of ignorance creates difficulties and profoundly hurts the sentiments of the Muslim community. The rise of Islamophobia in the West has caused concern among scholars and policymakers.

Islamophobia has reached levels unprecedented in the West. The analysis in this paper shows that the fear of Muslims and the perceived threats cause significant variation in the world attitude. Western citizens view Muslims as fanatical, violent, and supportive of terrorism because they perceive it as threatening their physical well-being and cultural value. The media and right-wing leaders are using this feeling to feed a new kind of xenophobia.

It seems that if radical Muslims are more often portrayed as terrorists than other attackers, the public could potentially also adopt negative opinions about Islam. Many studies have shown that reporting about terrorism can provoke fear in individuals. However, the level of anxiety may vary "depending on the specific information provided or the way the terrorism news is presented". This is why the media and news agencies need to have the right tools and processes to avoid creating stereotypes or promoting fear of particular communities.

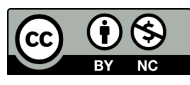

DOI: 10.19105/karsa.v29i1.3793 
Meanwhile, the mainstream media and some political leaders associate Islam with violence, the report said by a leading organization that focuses on the general dislike of Muslims.

\section{Bibliography}

Age, The. and Herald Sun. "The Representation of Islam and Muslims in the Media (The Age and Herald Sun Newspapers) School of Political and Social Inquiry." Islam Zeitschrift Für Geschichte Und Kultur Des Islamischen Orients, no. November (2005). http://asiainstitute.unimelb.edu.au/_data/assets/pdf_file/0017/57 1112/Islam-in-the-Media.pdf.

Agha, O. H. Islamic Fundamentalism and Its Image in the Western Media._al_Ahram Centre for Political et Strategic Studies., 1995. Archer, Toby. "Welcome to the umma: The British state and its Muslim citizens since 9/11." Cooperation and Conflict 44, no. 3 (2009): 329-47. https://doi.org/10.1177/0010836709106219.

Awass, O. The representation of Islam in the American Media. Hamdard Islamicus, 1996.

Carlson, Joseph L. “After 9/11.” Library Journal 128, no. 9 SUPPL. (2003): 16-17. https://doi.org/10.35632/ajiss.v21i3.506.

Dunn, K. M. "Representations of Islam in the politics of mosque development in Sydney." Tijdschrift voor Economische en Sociale Geografie 92, no. 3 (2001): 291-308. https://doi.org/10.1111/ 1467-9663.00158.

Eid, Mahmoud. "Perceptions about muslims in western societies." ReImagining the Other: Culture, Media, and Western-Muslim Intersections, 2014, 99-119. https://doi.org/10.1057/9781137 403667.

Entman, Robert M. "Framing: Toward Clarification of a Fractured Paradigm SUPER RELEVANT TIL.” Journal of Communication 43, no. 4 (1993): 51-58.

—. "How the Media Affect What People Think: An Information Processing Approach." The Journal of Politics 51, no. 2 (1989): 347-70. https://doi.org/10.2307/2131346.

European Islamophobia Report, 2016

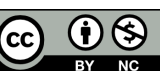

DOI: 10.19105/karsa.v29i1.3793 
Lewis, J. Language wars: The role of media and culture in global terror and political violence. Pluto Press., 2005.

McQuail, D. Mass Communication Theory: An Introduction. California: Sage, n.d.

Miller, David, A Briggs Editor, and P Cobley (ed.) "Promotion and Power," n.d.

Modood, Tariq. "Remaking multiculturalism after 7/7." Integration The Vlsi Journal, no. August (2005): 1-7. https://www.surrey.ac. $\mathrm{uk} / \mathrm{cronem} /$ files/Tariq-Modood-article.pdf.

Onur Bahçecik, Şerif. "Internationalizing Islamophobia: AntiIslamophobic Practices from the Runnymede Trust to the Organization of Islamic Cooperation." Ortadogu Etutleri 5, no. 1 (2013): 90. http://www.orsam.org.tr/files/OE/5-1/makale6.pdf.

Poole, Elizabeth. Reporting Islam. Reporting Islam, 2002. https://doi. org/10.5040/9780755604579.

Powell, Kimberly A. "Framing Islam: An analysis of U.S. media coverage of terrorism since 9/11." Communication Studies, 2011. https://doi.org/10.1080/10510974.2011.533599.

-. "Framing islam: An analysis of U.S. media coverage of terrorism since 9/11." Communication Studies 62, no. 1 (2011): 90-112. https://doi.org/10.1080/10510974.2011.533599.

Ridouani, Driss. "The Representation of Arabs and Muslims in Western Media." RUTA: revista universitària de treballs acadèmics, no. 3 (2011).

Ryan, Charlotte, Kevin M. Carragee, and William Meinhofer. "Framing, the news media, and collective action." Journal of Broadcasting \& Electronic Media 45, no. 1 (2001): 175-82. https://doi.org/10. 1207/s15506878jobem4501.

Saeed, Amir. "Teaching and Learning Guide for: Media, Racism and Islamophobia: The Representation of Islam and Muslims in the Media." Sociology Compass 2, no. 6 (2008): 2041-47. https://doi. org/10.1111/j.1751-9020.2008.00160.x.

Ahmed, Saifuddin, and Jörg Matthes. "Media representation of Muslims and Islam from 2000 to 2015: a Meta-Analysis." International Communication Gazette 79, no. 3 (2017): 219-44. https://doi.org/ $10.1177 / 1748048516656305$.

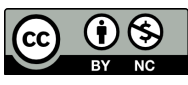

DOI: 10.19105/karsa.v29i1.3793 